\title{
Is low radioiodine uptake a contraindication to radioiodine therapy in patients with benign thyroid disease?
}

\author{
Maria Teresa Płazińskaa ${ }^{1, A, B, D}$, Agata Czarnywojtek ${ }^{2,3, A, B, D}$, Nadia Sawicka-Gutaj3, , Kosma Wolińnkii ${ }^{4, D}$, \\ Iwona Krela-Kaźmierczak ${ }^{5, A}$, Małgorzata Zgorzalewicz-Stachowiak ${ }^{6, A, E}$, Izabela Miechowicz ${ }^{6, B, C}$, \\ Paweł Gut ${ }^{3, \mathrm{E}}$, Ewa Florek7, , Karolina Skonieczna-Żydecka ${ }^{8, \mathrm{E}}$, Marek Ruchała ${ }^{3, \mathrm{E}, \mathrm{F}}$, Leszek Królicki, ${ }^{1, \mathrm{E}, \mathrm{F}}$ \\ ${ }^{1}$ Department of Nuclear Medicine, Warsaw Medical University, Poland \\ ${ }^{2}$ Chair and Department of Pharmacology, Poznan University of University of Medical Sciences, Poland \\ ${ }^{3}$ Chair and Department of Endocrinology, Metabolism and Internal Medicine, Poznan University of University of Medical Sciences, Poland \\ ${ }^{4}$ Department of Endocrinology, Metabolism and Internal Medicine, Poznan University of Medical Sciences, Poland \\ ${ }^{5}$ Department of Gastroenterology, Dietetics and Internal Medicine, Poznan University of Medical Sciences, Poland \\ ${ }^{6}$ Department of Computer Science and Statistics, Poznan University of Medical Sciences, Poland \\ ${ }^{7}$ Laboratory of Environmental Research, Department of Toxicology, Poznan University of Medical Sciences, Poland \\ ${ }^{8}$ Department of Biochemistry and Human Nutrition, Pomeranian Medical University, Szczecin, Poland \\ A - research concept and design; B - collection and/or assembly of data; C - data analysis and interpretation; \\ $D$ - writing the article; $E$ - critical revision of the article; $F$ - final approval of the article
}

Address for correspondence

Kosma Woliński

E-mail: kosma1644@poczta.onet.pl

Funding sources

None declared

Conflict of interest

None declared

Received on March 31, 2019

Reviewed on July 4, 2019

Accepted on August 11, 2020

Published online on April 29, 2021

Cite as

Płazińska MT, Czarnywojtek A, Sawicka-Gutaj N, et al. Is low radioiodine uptake a contraindication to radioiodine therapy in patients with benign thyroid disease? Adv Clin Exp Med. 2021;30(4):369-378. doi:10.17219/acem/126287

DOI

10.17219/acem/126287

Copyright

Copyright by Author(s)

This is an article distributed under the terms of the

Creative Commons Attribution 3.0 Unported (CC BY 3.0)

(https://creativecommons.org/licenses/by/3.0/)

\section{Abstract}

Background. Radioiodine therapy $\left({ }^{131} \mid\right)$ is a standard procedure in the treatment of hyperthyroidism in the course of Graves' disease or toxic nodules. However, the use of ${ }^{131}$ I in patients with low radioiodine uptake (RAIU) may be controversial.

Objectives. To determine the influence of lithium carbonate (Li) on iodine kinetics.

Materials and methods. Patients with hyperthyroidism and low RAIU ( $<30 \%)$ were divided into 2 groups: a Li(-) group of 305 patients not receiving Li adjuvant therapy and a Li(+) group of 264 patients receiving adjuvant therapy. The serum concentrations of free triiodothyronine (fT3), free thyroxine (fT4) and thyroid stimulating hormone (TSH) were assessed at baseline, $24 \mathrm{~h}, 48 \mathrm{~h}, 72 \mathrm{~h}$ and $96 \mathrm{~h}$, and 1,6 and 12 months after ${ }^{131} 1$ therapy. The RAlU was assessed after $5 h, 24 h, 48 h, 72 h$, and $96 h$.

Results. Levels of fT3 in the Li(+) group compared to the Li(-) group were significantly higher at baseline, lower after $48 \mathrm{~h}, 72 \mathrm{~h}, 96 \mathrm{~h}$ and 1 month, and did not differ significantly after $24 \mathrm{~h}, 6$ months and 12 months. Levels of fT4 in the Li(+) group compared to the Li(-) group were significantly higher at baseline, lower after $24 \mathrm{~h}, 48 \mathrm{~h}, 72 \mathrm{~h}, 96 \mathrm{~h}$ and 1 month, and not differ significantly after 6 and 12 months. The RAIU in the hyperthyroidism Li(-) and Li(+) groups, respectively, was $11.9 \pm 5.6 \%$ compared to $23.9 \pm 10.1 \%$ $(p<0.001)$ after $5 h ; 25.9 \pm 8.3 \%$ compared to $40.5 \pm 12.4 \%$ ( $p<0.05)$ after $24 h ; 7.8 \pm 8.1 \%$ compared to $40.9 \pm 13.7 \%$ ( $p<0.05)$ after $48 \mathrm{~h} ; 26.2 \pm 10.2 \%$ compared to $39.5 \pm 11.2 \%(p<0.01)$ after $72 \mathrm{~h}$; and $24.7 \pm 7.1 \%$ compared to $37.4 \pm 10.1 \%(p<0.01)$ after $96 \mathrm{~h}$.

Conclusions. Adjuvant therapy with Li in patients with hyperthyroidism caused a significant increase in RAIU and positive changes in the fT3 and fT4 profiles. The use of lithium carbonate prior to the inclusion of ${ }^{131}$ I in hyperthyroid patients with low RAIU should be considered.

Key words: hyperthyroidism, radioiodine therapy, lithium therapy, adjuvant lithium therapy, low radioiodine uptake 


\section{Background}

Lithium carbonate (Li), which is a drug known for over 100 years, is successfully used in the treatment of depression. However, various studies have shown that it can cause the emergence of goiter and even hypothyroidism in the range of $3.4-52 \%$ of treated patients ${ }^{1-9}$ and, in extremely rare cases, hyperthyroidism. ${ }^{1,10,11}$ The mechanism of action of Li on thyroid function seems to be similar to that of iodine. It is believed that ionized lithium inhibits thyroglobulin proteolysis which, in turn, inhibits the release of thyroid hormones into the bloodstream and leads to a prolonged biological half-life of iodine. ${ }^{12}$ Another mechanism involves inhibition of the conversion of free thyroxine (T4) to triiodothyronine (T3) by this drug. ${ }^{1}$ Lithium carbonate has also been shown to reduce the concentration of thyroid hormone transporter proteins in the blood serum. ${ }^{1,13}$

Radioiodine $\left({ }^{131} \mathrm{I}\right)$ therapy is a very popular therapeutic method in patients with hyperthyroidism, ${ }^{14-18}$ especially in cases where antithyroid drugs (ATDs) have proved to be inefficient. The mechanism of action of ${ }^{131}$ I involves the total destruction of thyroid tissues, resulting in euthyroidism or hypothyroidism. ${ }^{19,20}$ However, it is very difficult to choose the right activity of ${ }^{131}$ I to achieve euthyroidism. Several studies have attempted to determine the optimal level to treat hyperthyroidism while avoiding the development of permanent hypothyroidism. Various ${ }^{131} \mathrm{I}$ administration protocols are available, including low doses $(80 \mathrm{MBq}),{ }^{14,21,22}$ various fixed doses (185 MBq, $370 \mathrm{MBq}$ and $555 \mathrm{MBq}),{ }^{14,22-24}$ and doses calculated on the basis of thyroid size, radioactive iodine uptake (RAIU) or the turnover of ${ }^{131}{ }^{1} \cdot{ }^{14,24,25}$ However, our clinical experience has proven that hypothyroidism develops in approx. $80 \%$ of cases, which is not a significant problem for an experienced clinician, as it only requires the substitution of L-thyroxin. ${ }^{26}$

The premise for using $\mathrm{Li}$ is that this compound leads to the inhibition of thyroglobulin proteolysis and release of thyroid hormones. ${ }^{1}$ Therefore, it is assumed that the administered radioactive iodine accumulates in thyroid tissue to a higher degree, and thus ${ }^{131}$ I treatment is possible in patients with critically reduced RAIU at baseline. However, in the existing literature, there is relatively little data on the long-term results of the use of $\mathrm{Li}$ in patients with hyperthyroidism, especially those with a low radioiodine uptake (RAIU) after or during treatment with amiodarone, ${ }^{1,13,26,27}$ after coronary angiography, or in cases using iodine-containing contrast (e.g., eye drops or multivitamin preparations). Additionally, there are few publications related to the use of this type of therapy and the available publications have too short observation period or too few patients. Therefore, a method involving the administration of Li to hyperthyroid patients was introduced. ${ }^{28}$

\section{Objectives}

The aim of this study was to demonstrate the usefulness and effectiveness of the administration of Li prior to the administration of ${ }^{131} \mathrm{I}$ in patients with established hyperthyroidism for whom the reduced RAIU did not allow this type of treatment.

\section{Materials and methods}

\section{Patients and study design}

This retrospective study was conducted at the Department of Nuclear Medicine in Warszawa, Poland, from January 1,2005, to December 31,2016. The study was approved by the local ethics committee of the county of Warszawa. Our cohort comprised 569 consecutive patients with hyperthyroidism with reduced RAIU at baseline $(<30 \%)$ and 78 patients with normal or elevated RAIU (comparison group) treated with ${ }^{131} \mathrm{I}$. Data were retrieved from the medical records of patients who were eligible for this study. Informed consent was obtained from all participants.

The patients were categorized into 3 following groups:

- group I (Li (-) group): patients with very low RAIU (<30\%), with Graves' disease (GD), toxic nodular goiter (TNG) or iodine-induced toxic adenoma (TA) not treated with Li;

- group II (Li(+) group): patients who received Li in order to increase RAIU ( $>30 \%$ ), with GD, TNG or TA; and

- group III: the comparison group comprising hyperthyroid patients with GD treated with ${ }^{131}$ I with correct or elevated RAIU at baseline.

Among the included patients, low RAIU was caused by amiodarone therapy ( $\mathrm{n}=186,32.7 \%)$, coronary angiography before the iodine uptake test $(n=281,49.4 \%)$, iodinecontaining eye drops (e.g., Iodoxouridine; $\mathrm{n}=57,10.0 \%$ ), and multivitamin preparations containing iodine $(n=45,7.9 \%)$.

The etiology of hyperthyroidism was established on the basis of clinical examination and history of the disease. The following diagnostic criteria for GD were applied: 1) biochemical hyperthyroidism (increased serum free T4 concentration and undetectable TSH) and diffuse goiter without nodules, with or without an isotopic scan; 2) the presence of the titer of the TSH receptor antibody (TRAb); and 3) symptoms of mild ophthalmopathy.

The TNG was defined as hyperthyroidism with the presence of nodular goiter on thyroid ultrasonography and ${ }^{131} \mathrm{I}$ scintigraphy and, in the case of toxic adenoma, clinical or subclinical hyperthyroidism and the presence of hot nodules on scintigraphy.

The diagnosis of mild GO was defined based on the following criteria: goiter on thyroid ultrasound, mild proptosis or mild exophthalmos assessed using an exophthalmometer $(<18 \mathrm{~mm})$, and hormonal analyses showing suppressed TSH levels, as well as an increased concentration of free T4 
(fT4) and free T3 (fT3) combined with positive autoantibodies in regard to the thyrotropin receptor (TSHR-Abs).

Patients with GD for whom long-term remission did not appear following ATDs treatment, and patients with persistent hyperthyroidism due to toxic multinodular goiter or single toxic adenoma, were administered ${ }^{131}$ I.

\section{Study design}

Using a thyroid uptake probe, we counted 2 capsules of $25 \mu \mathrm{Ci}{ }^{131} \mathrm{I}$, each kept in a neck phantom. A standard distance of $30 \mathrm{~cm}$ was maintained from the phantom for the purpose of the count. We acquired 2 readings of $100 \mathrm{~s}$ for each capsule and, subsequently, expressed the average of the 2 readings as counts per minute (cpm). The first capsule was administered if the average count of the 2 capsules amounted to $\pm 10 \%$, and the patient was asked to swallow it with plain water. The $2^{\text {nd }}$ capsule, labelled the 'standard capsule', was kept in the neck phantom. Following administration of this capsule, the patient's thyroid and thigh counts were measured using a thyroid uptake probe at $5 \mathrm{~h}, 24 \mathrm{~h}, 48 \mathrm{~h}, 72 \mathrm{~h}$, and $96 \mathrm{~h}$ at the same distance and for the same time; the results were expressed as cpm. The patient's thigh counts were used for the correction of non-thyroidal blood pool activity. The source, which was kept inside the lucite thyroid phantom, was located $30 \mathrm{~cm}$ from the detector (isoresponse distance). Counts were taken at specific times after each patient's readings, namely at 5 h, 24 h, 48 h, 72 h, and 96 h, with the reading expressed in the standard capsule cpm. The following formula was used to calculate the percentage uptake:

$$
\begin{aligned}
& \qquad \text { percentage uptake }= \\
& =\text { thyroid counts }[\mathrm{cpm}]-\text { thigh counts }[\mathrm{cpm}] \times 100 .
\end{aligned}
$$

Iodine sensitivity tests were performed using a Siemens ZLC gamma camera (Siemens AG, Munich, Germany).

After performing RAIU and obtaining the activity of ${ }^{131} \mathrm{I}$, patients were scheduled to visit outpatient clinics at baseline (before radioiodine therapy (RIT)), and at $24 \mathrm{~h}$, $48 \mathrm{~h}, 72 \mathrm{~h}$ and $96 \mathrm{~h}$ after the procedure, and after 1, 6 and 12 months during 1 year of follow-up after the initiation of RIT. The TSH, fT3, fT4, and thyroid autoantibodies were examined at every follow-up visit to the outpatient clinic.

Our study did not include patients with contraindications to Li, i.e., allergy to lithium, heart and kidney failure, hypothyroidism, uncontrolled arterial hypertension, water-electrolyte disorders, Addison's disease, or brain diseases with dementia.

\section{Treatment}

\section{Antithyroid drug}

The ATD therapy was discontinued in all patients before ${ }^{131}$ I therapy. Most patients (83\%) did not receive ATD for 5-7 days before ${ }^{131}$ I treatment. The TD treatment was discontinued in all other patients for a period of more than 7 days (7-25 days).

\section{Lithium carbonate}

Oral administration of adjuvant Li (GlaxoSmithKline Pharmaceuticals SA, Poznań, Poland) was recommended for patients with low RAIU. Patients were assigned to receive a daily oral average dose of $750 \mathrm{mg}$ starting 3 days prior to ${ }^{131}$ I therapy and continuing for 7 days following the administration of ${ }^{131} \mathrm{I}$.

\section{Radioiodine therapy}

Radioactive iodine was administered as a single, standard, orally administered dose of $740 \mathrm{MBq}(20 \mathrm{mCi})$ in patients with GD and TMG (with adjuvant lithium therapy (750 mg/day for 10 days) or without lithium). The administered activity of ${ }^{131} \mathrm{I}$ in TA was $555 \mathrm{MBq}(15 \mathrm{mCi})$, irrespective of adjuvant Li therapy.

\section{L-thyroxine}

In all patients with hypothyroidism $(\mathrm{TSH}>4.5 \mathrm{mIU} / \mathrm{L})$ after ${ }^{131}$ I therapy, L-thyroxin therapy was applied.

\section{Assays}

A Hitachi Cobas e601 chemiluminescent analyzer (Roche Diagnostics, Basel, Switzerland) was used to diagnose serum TSH levels (normal range: 0.27-4.2 $\mu \mathrm{IU} / \mathrm{mL}$ ) and to perform the hormonal assessments $\mathrm{fT} 4$, normal range: 11.5-21.5 pmol/L; fT3, normal range: 3.9-6.8 pmol/L). Determination of TSH concentrations was performed using third-generation assays (sensitivity: $0.005 \mu \mathrm{IU} / \mathrm{mL}$ ). Second-generation antibodies (RIA-2 Dynotest TRAK human; BRAHMS Diagnostica GmbH, Berlin, Germany) were the radioimmunological method used to measure the titer of the antithyroid peroxidase autoantibody (TPO-Abs, reference range: $<35 \mathrm{IU} / \mathrm{mL}$ ), antithyroglobulin antibody (Tg-Abs, reference range: $<115 \mathrm{IU} / \mathrm{mL}$ ) and TSHR-Abs (reference range: $<2$ IU/L).

The serum level of Li was assayed by ion-selective lithium determination using a lithium electrode and an AVL 988-3 apparatus with automatic three-point calibration. This method consists of determining the difference in the potential of the lithium level between the standard and the sample. The selective potential between the 2 different concentrations of lithium ions was automatically measured. Using this method, the measurement limit for lithium is in the range of $0.1 \pm 9.99 \mathrm{mmol} / \mathrm{L}$ and the sensitivity is $0.01 \pm 0.02 \mathrm{mmol} / \mathrm{L}$.

\section{Sonography and scintigraphy}

An Aloka SSD-500 (Aloka Ltd., Tokyo, Japan) ultrasound machine with a 7.5-MHz linear transducer was used 
to perform ultrasonography of the thyroid. Ultrasound was also used to measure the thyroid volume. The ellipsoid model (width $\times$ length $\times$ thickness $\times 0.52$ for each lobe) was used for the calculation. ${ }^{29,30}$

In the case of patients with thyroid nodules, $150 \mathrm{MBq}$ of ${ }^{99 \mathrm{~m} T c}$ was intravenously administered and a thyroid scintiscan was performed (Nucline gamma camera; Mediso, Budapest, Hungary) 30 min later.

\section{Statistical analyses}

The thyroid hormone and TSH serum levels before and after administration of Li were assessed using Student's t-test for independent observations. Friedman's test was also used for statistical comparison of mean iodine uptake measurements before and 5 h, 24 h, 48 h, 72 h, and $96 \mathrm{~h}$ after administration of Li. One-way analysis of variance (ANOVA) was used to establish if there was a statistically justified division of the analyzed data into subgroups of the various clinical forms of hyperthyroidism. Variance analysis was preceded by assessment of the compatibility of the variances of the hypothetical subgroups using Levene's test. The mean uptake of ${ }^{131} \mathrm{I}$ before and after the administration of Li for particular groups at the determined measurement times was also compared using Student's t-test. Statistical analyses were performed using STATISTICA v. 12 software (StatSoft Inc. Tulsa, USA). The adopted level of statistical significance was $\alpha=0.05$ and results were considered statistically significant when $\mathrm{p}<\alpha$.

Table 1A. Baseline characteristic of the hyperthyroid patients (GD, TMG and TA) with reduced RAIU at baseline $(<30 \%)$ according to the clinical diagnosis or the demographic, clinical and laboratory characteristics

\begin{tabular}{|c|c|c|c|c|c|c|}
\hline \multirow[t]{2}{*}{ Characteristic } & \multicolumn{2}{|c|}{$\begin{array}{c}\text { GD } \\
(n=284)\end{array}$} & \multicolumn{2}{|c|}{$\begin{array}{c}\text { TMG } \\
(n=231)\end{array}$} & \multicolumn{2}{|c|}{$\begin{array}{c}\text { TA } \\
(n=54) \\
\end{array}$} \\
\hline & $\mathrm{Li}(-)$ & $\mathrm{Li}(+)$ & $\mathrm{Li}(-)$ & $\mathrm{Li}(+)$ & $\mathrm{Li}(-)$ & $\mathrm{Li}(+)$ \\
\hline Females (n, \%) & $121(42.6)$ & $107(36.7)$ & $79(34.2)$ & $74(32.0)$ & $22(40.7)$ & $9(16.6)$ \\
\hline Males (n, \%) & $23(8.1)$ & $33(11.6)$ & $41(17.7)$ & $37(16.1)$ & $19(35.2)$ & $4(7.4)$ \\
\hline Age of females, mean (range) [years] & $49(18-61)$ & $45(19-54)$ & $51(37-81)$ & $54(34-78)$ & $54(33-71)$ & $55(29-87)$ \\
\hline Age of males, mean (range) [years] & $43(26-52)$ & $47(32-58)$ & $59(42-78)$ & $62(32-69)$ & $52(38-83)$ & $56(32-86)$ \\
\hline Week of diagnosis & 23 & 17 & 27 & 20 & 13 & 11 \\
\hline $\begin{array}{l}\text { Mild ophthalmopathy } \\
\text { yes (\%) } \\
\text { no (\%) }\end{array}$ & $\begin{array}{l}96(67) \\
48(33)\end{array}$ & $\begin{array}{l}102(73) \\
38(27)\end{array}$ & $\begin{array}{c}0(0) \\
120(52)\end{array}$ & $\begin{array}{c}0(0) \\
111(48)\end{array}$ & $\begin{array}{c}0(0) \\
41(76)\end{array}$ & $\begin{array}{c}0(0) \\
13(24)\end{array}$ \\
\hline $\begin{array}{l}\text { TSH level }[\mathrm{mIU} / \mathrm{L}] \\
\text { mean (SEM) } \\
\text { range }\end{array}$ & $\begin{array}{l}0.0(0.09) \\
0.0-0.012\end{array}$ & $\begin{array}{l}0.0(0.04) \\
0.0-0.05\end{array}$ & $\begin{array}{c}0.13(0.04) \\
0.1-0.21\end{array}$ & $\begin{array}{l}0.1(0.15) \\
0.01-0.20\end{array}$ & $\begin{array}{l}0.15(0.1) \\
0.14-0.23\end{array}$ & $\begin{array}{c}0.18(0.13) \\
0.1-0.22\end{array}$ \\
\hline $\begin{array}{l}\text { Free T3 level [pmol/L] } \\
\text { mean (SEM) } \\
\text { range }\end{array}$ & $\begin{array}{l}9.6(3.8) \\
3.9-12.7\end{array}$ & $\begin{array}{l}8.7(5.2) \\
4.6-11.2\end{array}$ & $\begin{array}{l}6.6(3.1) \\
3.3-8.4\end{array}$ & $\begin{array}{l}4.3(4.1) \\
3.6-9.6\end{array}$ & $\begin{array}{l}4.3(3.9) \\
3.6-5.7\end{array}$ & $\begin{array}{l}3.9(4.2) \\
4.1-6.2\end{array}$ \\
\hline $\begin{array}{l}\text { Free T4 level [pmol/L] } \\
\text { mean (SEM) } \\
\text { range }\end{array}$ & $\begin{array}{l}29.1(5.6) \\
25.0-39.7\end{array}$ & $\begin{array}{c}32.2(6.7) \\
24-45\end{array}$ & $\begin{array}{c}26(3.9) \\
35.5-32.5\end{array}$ & $\begin{array}{l}23.91(4.6) \\
22.4-32.3\end{array}$ & $\begin{array}{l}22.9(4.1) \\
18.9-25.9\end{array}$ & $\begin{array}{l}21.71(3.5) \\
20.4-27.1\end{array}$ \\
\hline $\begin{array}{l}\text { TSHR-Abs titers [IU/L] } \\
\text { mean (SEM) } \\
\text { range }\end{array}$ & $\begin{array}{l}12.1(5.6) \\
2.1-16.7\end{array}$ & $\begin{array}{l}7.8(4.8) \\
2.5-13.7\end{array}$ & $\begin{array}{l}0.9(0.6) \\
0.3-2.4\end{array}$ & $\begin{array}{l}1.1(0.5) \\
0.5-1.3\end{array}$ & $\begin{array}{l}1.2(0.5) \\
0.4-1.7\end{array}$ & $\begin{array}{l}2.0(0.6) \\
0.4-2.1\end{array}$ \\
\hline $\begin{array}{l}\text { TPO-Abs titers [IU/mL] } \\
\text { mean (SEM) } \\
\text { range }\end{array}$ & $\begin{array}{c}332.6(349.4) \\
79-451\end{array}$ & $\begin{array}{c}249.4(284.8) \\
134-456\end{array}$ & $\begin{array}{l}64.5(34.1) \\
19.0-71.3\end{array}$ & $\begin{array}{l}56.1(32.5) \\
31.0-81.7\end{array}$ & $\begin{array}{l}52.2(22.5) \\
19.5-49.3\end{array}$ & $\begin{array}{l}45.7(25.3) \\
28.5-47.3\end{array}$ \\
\hline $\begin{array}{l}\text { Tg-Abs titer [IU/mL] } \\
\text { mean (SEM) } \\
\text { range }\end{array}$ & $\begin{array}{c}319.2(295.7) \\
214-546\end{array}$ & $\begin{array}{c}329.3(254) \\
212-634\end{array}$ & $\begin{array}{l}102.9(71.4) \\
49.5-183.0\end{array}$ & $\begin{array}{l}114.6(93.5) \\
39.3-161.7\end{array}$ & $\begin{array}{l}91.3(76.6) \\
29.5-137\end{array}$ & $\begin{array}{l}89.3(88.3) \\
53.4-192.6\end{array}$ \\
\hline $\begin{array}{l}\text { Thyroid volume }\left[\mathrm{mL} / \mathrm{m}^{2}\right] \\
\text { mean }(\mathrm{SEM}) \\
\{\text { Me; } \min -\max \}\end{array}$ & $\begin{array}{c}21.0(3.4) \\
\{19.0 ; 17.8-25.4\}\end{array}$ & $\begin{array}{c}24.9(5.7) \\
\{21.8 ; 20.8-25.4\}\end{array}$ & $\begin{array}{c}19.0(2.4) \\
\{17.2 ; 15.8-21.4\}\end{array}$ & $\begin{array}{c}21.6(3.6) \\
\{18.8 ; 17.7-25.2\}\end{array}$ & $\begin{array}{c}17.5(2.7) \\
\{16.9 ; 15.1-22.3\}\end{array}$ & $\begin{array}{c}20.9(4.8) \\
\{17.6 ; 16.5-24.3\}\end{array}$ \\
\hline Activity of ${ }^{131}$ I [MBq] ([mCi]) & $\begin{array}{l}800(0.0) \\
22(0.0)\end{array}$ & $\begin{array}{l}800(0.0) \\
22(0.0)\end{array}$ & $\begin{array}{l}800(0.0) \\
22(0.0)\end{array}$ & $\begin{array}{l}800(0.0) \\
22(0.0)\end{array}$ & $\begin{array}{l}555(15) \\
555(15)\end{array}$ & $\begin{array}{l}555(15) \\
555(15)\end{array}$ \\
\hline
\end{tabular}

TSH - thyroid stimulating hormone; fT4 - free tetraiodothyroxine; fT3 - free triiodothyronine; TPO-Abs - thyroperoxidase autoantibodies; Tg-Abs - thyroglobulin autoantibodies; TSHR-Abs - autoantibodies to the thyrotropin receptor; ${ }^{131}$ I - radioiodine; mCi - millicurie; SEM - standard error of the mean; min - minimum; max - maximum; Me - median.

Data are given as $n$, mean (SEM, range, \%). Normal values in our laboratory are as follows: fT4: 11.5-21.5 pmol/L; fT3: 3.9-6.8 pmol/L; TSH: 0.27-4.2 $\mu \mathrm{U} / \mathrm{mL}$; TSHR-Abs: <2 IU/L, TPO-Abs: 0-34 IU/mL and Tg-Abs: 10-115 IU/mL. All patients had undetectable serum Tg-Ab, TPO-Ab and TSHR-Abs. Thyroid volume was measured with ultrasonography (normal values range up to $19 \mathrm{~mL}$ for $\mathrm{F}$ and up to $25 \mathrm{~mL}$ for M). 


\section{Results}

Of the 678 patients assessed, 109 were eligible for inclusion in this study. The reasons for ineligibility were: incomplete medical records for 38 (35\%) patients (27 women and 11 men), retrosternal goiter in 35 (32\%) patients (23 males and 12 females); severe Graves' ophthalmopathy in 13 (12\%) female patients, and mental disease in $11(10 \%)$ patients, while 12 (11\%) patients did not agree to participate.

The demographic, clinical and laboratory characteristics of the cohort at presentation are summarized in Table 1A,1B. Between 2005 and 2016, we were able to obtain follow-up data for 569 hyperthyroid patients with reduced RAIU at baseline (<30\%). Of these, 284 were classified as suffering from GD (228 women and 56 men), 231 (153 women and 78 men) developed TMG and 54 ( 31 women and 23 men) were assigned to the group with TA.
Adjuvant lithium increased RAIU in all hyperthyroid patients (Table 2). For the hyperthyroidism $\mathrm{Li}(-)$ and $\mathrm{Li}(+)$ groups, respectively, the RAIU at the following time points (T) was: $\mathrm{T}_{5 \mathrm{~h}}, 11.9 \pm 5.6 \%$ compared to $23.9 \pm 10.1 \%$ ( $\left.<<0.001\right)$; $\mathrm{T}_{24 \mathrm{~h}}, 25.9 \pm 8.3 \%$ compared to $40.5 \pm 12.4 \%$ ( $\left.\mathrm{p}<0.05\right)$; $\mathrm{T}_{48 \mathrm{~h}}, 27.8 \pm 8.1 \%$ compared to $40.9 \pm 13.7 \%(\mathrm{p}<0.05) ; \mathrm{T}_{72 \mathrm{~h}}$, $26.2 \pm 10.2 \%$ compared to $39.5 \pm 11.2 \%(\mathrm{p}<0.01)$; and $\mathrm{T}_{96 \mathrm{~h}}$, $24.7 \pm 7.1 \%$ compared to $37.4 \pm 10.1 \%$ ( $<<0.01$ ). In the comparison group, RAIU was $31.3 \% \pm 10.2 \%$ at $\mathrm{T}_{5 \mathrm{~h}}, 52.3 \% \pm 6.9 \%$ at $\mathrm{T}_{24 \mathrm{~h}}, 54.9 \pm 12.7 \%$ at $\mathrm{T}_{48 \mathrm{~h}}, 47.5 \pm 10.8 \%$ at $\mathrm{T}_{72 \mathrm{~h}}$, and $38.5 \pm 9.2 \%$ at $\mathrm{T}_{96 \mathrm{~h}}$.

In the $\mathrm{Li}(+)$ group, the RAIU before administration of lithium was $12.0 \pm 4.4 \%$ at $\mathrm{T}_{5 \mathrm{~h}}, 25.0 \pm 5.4 \%$ at $\mathrm{T}_{24 \mathrm{~h}}$ and $24.0 \pm 6.0 \%$ at $\mathrm{T}_{96 \mathrm{~h}}$ ( $\mathrm{p}>0.05$ for all 3 time points in comparison to the $\mathrm{Li}(-)$ group).

Table 1B. Clinical and biochemical characteristic of the Li(-) and Li(+) and comparison groups at baseline

\begin{tabular}{|c|c|c|c|}
\hline \multirow{2}{*}{ Characteristic } & \multicolumn{2}{|c|}{ Examined groups } & \multirow{2}{*}{ Comparison group } \\
\hline & $\mathrm{Li}(-)$ & $\mathrm{Li}(+)$ & \\
\hline Females (n, \%) & $222(39.0)$ & $190(33.4)$ & 57 (37.0) \\
\hline Males (n, \%) & $83(14.9)$ & $74(13.00)$ & $21(27.0)$ \\
\hline Age of females, mean (range) [years] & $52(32-81)$ & $53(29-87)$ & $51(19-59)$ \\
\hline Age of males, mean (range) [years] & $51(26-83)$ & $55(27-86)$ & $47(21-52)$ \\
\hline Week of diagnosis & $13-27$ & $11-20$ & $12-25$ \\
\hline $\begin{array}{l}\text { Mild ophthalmopathy } \\
\text { yes (\%) } \\
\text { no (\%) }\end{array}$ & $\begin{array}{c}96(17) \\
209(37)\end{array}$ & $\begin{array}{l}102(18) \\
162(28)\end{array}$ & $\begin{array}{l}46(59) \\
32(41)\end{array}$ \\
\hline $\begin{array}{l}\text { TSH level }[\mathrm{m} / \mathrm{U} / \mathrm{L}] \\
\text { mean (SEM) } \\
\text { range }\end{array}$ & $\begin{array}{c}0.09(0.07) \\
0.0-0.23\end{array}$ & $\begin{array}{l}0.0(0.12) \\
0.01-0.22\end{array}$ & $\begin{array}{l}0.0(0.04) \\
0.00-0.19\end{array}$ \\
\hline $\begin{array}{l}\text { Free T3 level }[\mathrm{pmol} / \mathrm{L}] \\
\text { mean (SEM) } \\
\text { range }\end{array}$ & $\begin{array}{l}5.6(3.6) \\
3.3-12.7\end{array}$ & $\begin{array}{l}8.2(4.1) \\
3.9-6.2\end{array}$ & $\begin{array}{l}5.6(3.3) \\
3.1-7.4\end{array}$ \\
\hline $\begin{array}{l}\text { Free T4 level [pmol/L] } \\
\text { mean (SEM) } \\
\text { range }\end{array}$ & $\begin{array}{l}26.0(4.5) \\
25-32.5\end{array}$ & $\begin{array}{l}29.3(5.8) \\
20.4-32.3\end{array}$ & $\begin{array}{l}27.4(6.7) \\
21.9-33.6\end{array}$ \\
\hline $\begin{array}{l}\text { TSHR-Abs titers [IU/L] } \\
\text { mean (SEM) } \\
\text { range }\end{array}$ & $\begin{array}{l}4.7(2.2) \\
0.9-13.4\end{array}$ & $\begin{array}{l}3.6(1.9) \\
1.1-5.7\end{array}$ & $\begin{array}{l}6.7(2.8) \\
2.4-11.2\end{array}$ \\
\hline $\begin{array}{l}\text { TPO-Abs titers [IU/mL] } \\
\text { mean (SEM) } \\
\text { range }\end{array}$ & $\begin{array}{c}149.7(135.3) \\
39.1-190.5\end{array}$ & $\begin{array}{c}117.0(114.2) \\
64.5-195.0\end{array}$ & $\begin{array}{c}189(345.8) \\
116.0-1285.0\end{array}$ \\
\hline $\begin{array}{l}\text { Tg-Abs titer }[\mathrm{IU} / \mathrm{mL}] \\
\text { mean (SEM) } \\
\text { range }\end{array}$ & $\begin{array}{c}171.1(147.9) \\
97.6-307.2\end{array}$ & $\begin{array}{l}177.3(145.3) \\
113.2-329.4\end{array}$ & $\begin{array}{l}231.7(198.4) \\
98.2-1121.0\end{array}$ \\
\hline $\begin{array}{l}\text { Thyroid volume }\left[\mathrm{mL} / \mathrm{m}^{2}\right] \\
\text { mean (SEM) } \\
\{\text { Me; min-max }\}\end{array}$ & $\begin{array}{c}15.6(2.9) \\
\{15.7 ; 14.1-54.1\}\end{array}$ & $\begin{array}{c}18.9(3.6) \\
\{16.5 ; 13.4-43.3\}\end{array}$ & $\begin{array}{c}21.5(4.7) \\
\{17.5 ; 16.4-42.3\}\end{array}$ \\
\hline Activity of ${ }^{131} \mid$ [MBq] ([mCi]) & $814(22)$ & $814(22)$ & $185.0-814.0(5-22)$ \\
\hline
\end{tabular}

TSH - thyroid stimulating hormone; fT4 - free tetraiodothyroxine; fT3 - free triiodothyronine; TPO-Abs - thyroperoxidase autoantibodies; Tg-Abs - thyroglobulin autoantibodies; TSHR-Abs - autoantibodies to the thyrotropin receptor; ${ }^{131}$ I - radioiodine; mCi - millicurie; SEM - standard error of the mean; min - minimum; max - maximum; Me - median.

Data are given as n, mean (SEM, range, \%). Normal values in our laboratory are as follows: fT4: 11.5-21.5 pmol/L; fT3: 3.9-6.8 pmol/L; TSH: 0.27-4.2 $\mu \mathrm{U} / \mathrm{mL}$; TSHR-Abs: <2 IU/L, TPO-Abs: 0-34 IU/mL and Tg-Abs: 10-115 IU/mL. All patients had undetectable serum Tg-Ab, TPO-Ab and TSHR-Abs. Thyroid volume was measured with ultrasonography (normal values range up to $19 \mathrm{~mL}$ for $\mathrm{F}$ and up to $25 \mathrm{~mL}$ for M). 
Table 2. The mean iodine uptake values (RAIU) in all studied groups

\begin{tabular}{|l|c|c|c|c|}
\hline \multicolumn{1}{|c|}{ Time of observation of RAIU [h] } & 5 & 24 & 48 & 72 \\
\hline $\mathrm{Li}(-)$ group [\%] & $11.9 \pm 5.6$ & $25.9 \pm 8.3$ & $27.8 \pm 8.1$ & $26.2 \pm 10.2$ \\
\hline $\mathrm{Li}(+)$ group [\%] & $23.9 \pm 10.1$ & $40.5 \pm 12.4$ & $40.9 \pm 13.7$ & $39.5 \pm 11.2$ \\
\hline Comparison group [\%] & $31.3 \pm 10.2$ & $52.3 \pm 6.9$ & $54.9 \pm 12.7$ & $37.4 \pm 10.1$ \\
\hline
\end{tabular}

\section{Thyroid hormone concentrations}

For the $\mathrm{Li}(-)$ and $\mathrm{Li}(+)$ groups, differences in the serum level of fT3 (Fig. 1) were recorded at most time points ( $\mathrm{p}=0.001$ ), except at $48 \mathrm{~h}$ and after 6 and to 12 months of follow-up. The initial concentration of fT3 in $\mathrm{Li}(+)$ patients was $8.2 \pm 4.1 \mathrm{pmol} / \mathrm{L}$, while that in ${ }^{131} \mathrm{I} \mathrm{Li}(-)$ patients was significantly lower at $5.6 \pm 3.6 \mathrm{pmol} / \mathrm{L}(\mathrm{p}<0.001)$. The fT3 level in ${ }^{131} \mathrm{ILi}(-)$ and ${ }^{131} \mathrm{I} \mathrm{Li}(+)$ patients at each time point was as follows: after $24 \mathrm{~h}, 8.1 \pm 3.9 \mathrm{pmol} / \mathrm{L}$ compared to $6.2 \pm 3.2 \mathrm{pmol} / \mathrm{L}$; after $48 \mathrm{~h}, 8.1 \pm 3.9 \mathrm{pmol} / \mathrm{L}$ compared to $7.8 \pm 4.1 \mathrm{pmol} / \mathrm{L}$; after $72 \mathrm{~h}, 8.3 \pm 4.4 \mathrm{pmol} / \mathrm{L}$ compared to $6.3 \pm 3.9 \mathrm{pmol} / \mathrm{L}$; after $96 \mathrm{~h}, 8.4 \pm 3.4 \mathrm{pmol} / \mathrm{L}$ compared to $6.0 \pm 3.1 \mathrm{pmol} / \mathrm{L}$; after 1 month, $8.7 \pm 4.5 \mathrm{pmol} / \mathrm{L} \mathrm{com}-$ pared to $7.1 \pm 5.1 \mathrm{pmol} / \mathrm{L}$; after 6 months, $4.9 \pm 3.1 \mathrm{com}-$ pared to $5.1 \pm 3.9 \mathrm{pmol} / \mathrm{L}$; and after 1 year, $3.1 \pm 3.7 \mathrm{pmol} / \mathrm{L}$ compared to $3.8 \pm 3.9 \mathrm{pmol} / \mathrm{L}$.

The baseline serum fT4 concentration in $\mathrm{Li}(+)$ patients was $29.3 \pm 5.8 \mathrm{pmol} / \mathrm{L}$, which was significantly higher than in $\mathrm{Li}(-)$ patients $(26.0 \pm 4.5 \mathrm{pmol} / \mathrm{L} ; \mathrm{p}=0.001)$. However, after $24 \mathrm{~h}$ and up to 1 month into the observation period, the fT4 concentration was significantly lower in the ${ }^{131} \mathrm{I} \mathrm{Li}(+)$ group compared to the ${ }^{131} \mathrm{I} \mathrm{Li}(-)$ group $(\mathrm{p}<0.001)$. After $24 \mathrm{~h}$, it was $27.9 \pm 3.9 \mathrm{pmol} / \mathrm{L}$ compared to $34.2 \pm 7.4 \mathrm{pmol} / \mathrm{L}$; after $48 \mathrm{~h}$, it was $27.3 \pm 3.8 \mathrm{pmol} / \mathrm{L}$ compared to $38.2 \pm 5.2 \mathrm{pmol} / \mathrm{L}$; after $72 \mathrm{~h}$, it was $25.7 \pm 4.8 \mathrm{pmol} / \mathrm{L}$ compared to $38.2 \mathrm{pmol} / \mathrm{L} \pm 5.2$; after $96 \mathrm{~h}$, it was $24.8 \pm 5.0 \mathrm{pmol} / \mathrm{L}$ compared to $38.2 \pm 5.2$ $\mathrm{pmol} / \mathrm{L}$; after $1 \mathrm{month}$, it was $29.3 \pm 4.2 \mathrm{pmol} / \mathrm{L}$ compared to $39.7 \pm 6.7 \mathrm{pmol} / \mathrm{L}$; after 6 months, it was $21.2 \pm 7.5 \mathrm{pmol} / \mathrm{L}$ compared to $19.5 \pm 6.1 \mathrm{pmol} / \mathrm{L}$; and after 1 year, it was $19.6 \pm 6.4 \mathrm{pmol} / \mathrm{L}$ compared to $18.1 \pm 3.9 \mathrm{pmol} / \mathrm{L}$ (Fig. 2).
Therefore, a significant reduction of fT4 and fT3 was observed in the $\mathrm{Li}(+)$ group compared to the $\mathrm{Li}(-)$ and comparison groups. This significant reduction was observed at each subsequent time point following ${ }^{131} \mathrm{I}$.

Comparison of the mean TSH serum concentrations of patients before and after administration of Li did not show a statistically significant difference $(\mathrm{p}>0.05)$. The average TSH level before administration of Li was $0.3 \mathrm{mIU} / \mathrm{L}$, and after administration of Li it was $0.45 \mathrm{mIU} / \mathrm{L}$. All patients who received Li underwent analysis of serum concentrations on the $7^{\text {th }}$ day of application, obtaining values from $0.34 \mathrm{mmol} / \mathrm{L}$ to $0.49 \mathrm{mmol} / \mathrm{L}$, with a mean value of $0.5 \pm 0.06 \mathrm{mmol} / \mathrm{L}$.

\section{Clinical thyroid status}

At 1 year, 462 patients (81.2\%) were successfully treated (hypothyroid or euthyroid) and 107 (18.8\%) remained hyperthyroid. Euthyroid status was achieved by about $10 \%$ of patients, including approx. $70 \%$ of $\mathrm{Li}(+)$ group patients with GD. In the group with TNG, this percentage was $43 \%$, including $74.7 \%$ in the $\mathrm{Li}(+)$ group; in the TA group, this percentage was approx. $76 \%$, including $71 \%$ in the $\mathrm{Li}(+)$ group. In addition, clinical signs were less pronounced during follow-up in patients in the $\mathrm{Li}(+)$ group. Among $\mathrm{Li}(+)$ group patients with GD, recurrent hyperthyroidism was observed in approx. $31 \%$ of patients with GD and $29 \%$ of patients with TMG, whereas no cases of recurrent hyperthyroidism were diagnosed in patients with TA, as judged from biochemical analysis, clinical symptoms and reduced demand for antithyroid medications (Table 3).

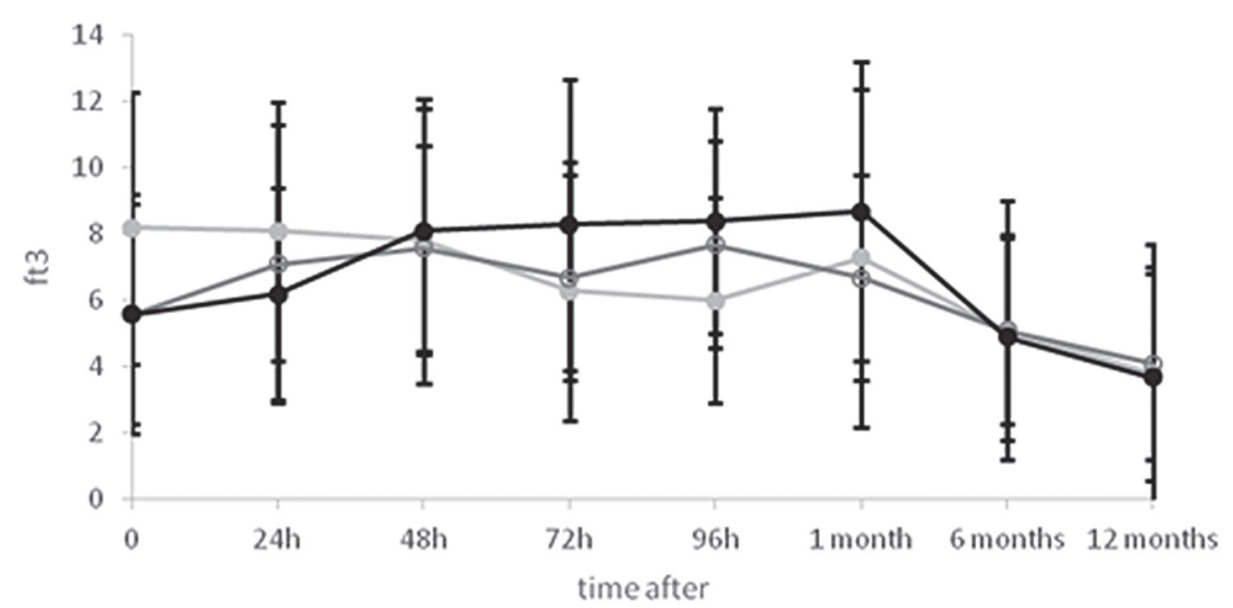

$\longrightarrow \mathrm{Li}(+) \longrightarrow$ Control $\longrightarrow \mathrm{Li}(-)$
Fig. 1. Serum fT3 concentrations for the Li(-) and $\mathrm{Li}(+)$ groups and the comparison group at baseline and at each subsequent time point following ${ }^{131}$ I administration 


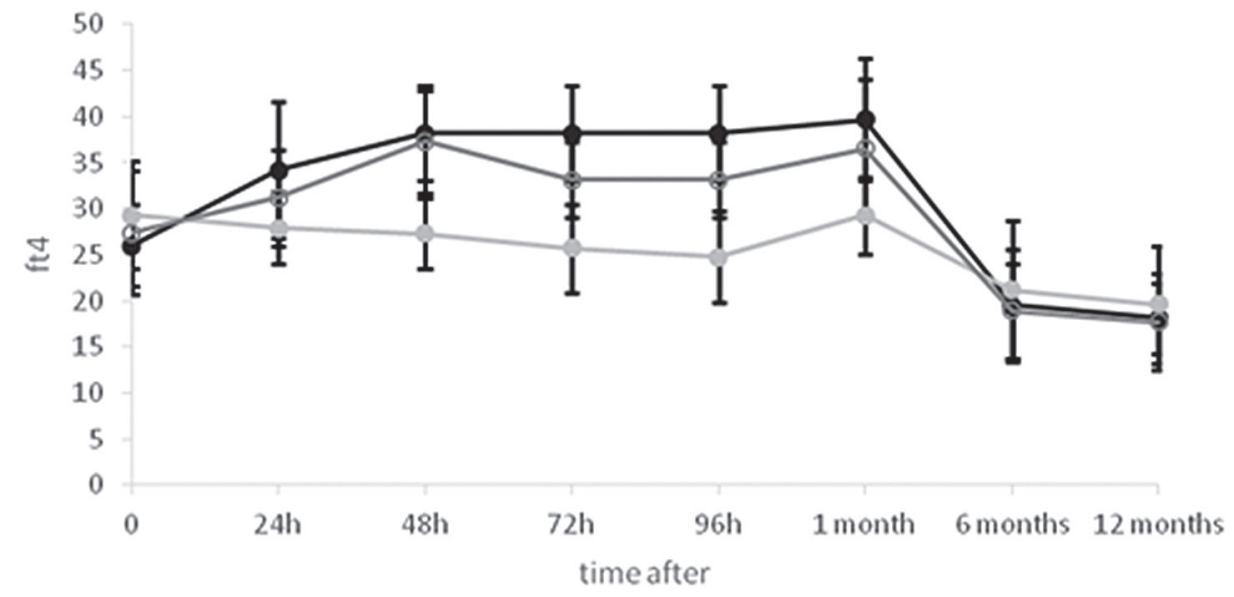

Fig. 2. Serum fT4 concentrations for the Li(-) and Li(+) groups and the comparison group at baseline and at each subsequent time point following ${ }^{131}$ I administration

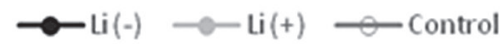

Table 3. Clinical outcome of a single fixed dose $\left(555(15 \mathrm{mCi})^{*} \mathrm{MBq}\right.$ or $\left.740 \mathrm{MBq}(20 \mathrm{mCi})\right)$ of radioiodine for all patients

\begin{tabular}{|c|c|c|c|c|c|}
\hline [Empty cell] & $\begin{array}{l}\text { Euthyroid } \\
\quad(n, \%) \\
(\mathrm{Li}(-), \% / \\
\mathrm{Li}(+), \%)\end{array}$ & $\begin{array}{l}\text { Hypothyroidism } \\
\text { (n,\%) } \\
(\mathrm{Li}(-), \% / \\
\mathrm{Li}(+), \%)\end{array}$ & $\begin{array}{l}\text { Hyperthyroidism } \\
(\mathrm{n}, \%) \\
(\mathrm{ii}(-), \% / \\
\mathrm{Li}(+), \%)\end{array}$ & 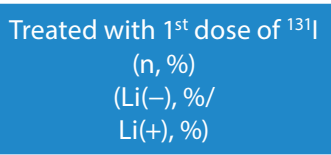 & $\begin{array}{c}\text { Treated with } 2^{\text {nd }} \text { dose of }{ }^{131} \mid \\
(\mathrm{n}, \%) \\
(\mathrm{Li}(-), \% / \\
\mathrm{Li}(+), \%)\end{array}$ \\
\hline $\begin{array}{l}G D \\
(n=284)\end{array}$ & $\begin{array}{l}28(9.8) \\
9(32.1) / \\
19(67.9)\end{array}$ & $\begin{array}{l}195(68.6) \\
84(43.1) / \\
111(56.9)\end{array}$ & $\begin{array}{l}61(21.6) \\
42(68.8) / \\
19(31.2)\end{array}$ & $\begin{array}{l}238(83.8) \\
187(78.6) / \\
51(21.4)\end{array}$ & $\begin{array}{l}46(16.2) \\
28(60.9) / \\
18(39.1)\end{array}$ \\
\hline $\begin{array}{l}\text { TMG } \\
(n=231)\end{array}$ & $\begin{array}{l}99(42.8) \\
25(25.3) / \\
74(74.7)\end{array}$ & $\begin{array}{c}90(39.0) \\
27(30.0) / \\
63(70.0)\end{array}$ & $\begin{array}{c}42(18.2) \\
30(71.4) / \\
12(28.6)\end{array}$ & $\begin{array}{l}193(33.9) \\
151(78.2) / \\
42(21.8)\end{array}$ & $\begin{array}{c}38(6.7) \\
31(81.6) / \\
7(18.4)\end{array}$ \\
\hline $\begin{array}{l}T A^{*} \\
(n=54)\end{array}$ & $\begin{array}{l}41(75.9) \\
12(29.3) / \\
29(70.7)\end{array}$ & $\begin{array}{l}9(16.7) \\
2(22.2) / \\
7(77.8)\end{array}$ & $\begin{array}{l}4(7.4) \\
4(100) / \\
-(-)\end{array}$ & $\begin{array}{l}49(8.6)^{*} \\
29(59.2) / \\
20(40.8)\end{array}$ & $\begin{array}{l}5(87.8) \\
3(60) / \\
2(40)\end{array}$ \\
\hline $\begin{array}{l}\text { All (mean) } \\
(n=569)\end{array}$ & $\begin{array}{l}168(29.5) \\
46(27.4) / \\
122(72.6)\end{array}$ & $\begin{array}{c}294(51.7) \\
113(38.4) / \\
181(61.6)\end{array}$ & $\begin{array}{c}107(18.8) \\
76(71.0) / \\
31(29.0)\end{array}$ & $\begin{array}{c}480(84.3) \\
367(76.5) / \\
113(23.5)\end{array}$ & $\begin{array}{l}89(15.6) \\
62(69.7) / \\
27(30.3)\end{array}$ \\
\hline $\begin{array}{l}\text { Comparison group } \\
(n=78)\end{array}$ & $21(26.9)$ & $40(51.3)$ & $17(21.8)$ & $63(80.8)$ & 15 (19.2) \\
\hline
\end{tabular}

* Administered activity of ${ }^{131}$ I in patients with toxic adenoma was in each case equal to $555 \mathrm{MBq}(15 \mathrm{mCi})$, while in other cases an "ablative" dose of $740 \mathrm{MBq}$ (20mCi) of ${ }^{131}$ I was used.

\section{Discussion}

Li is as a normothymic drug widely used in psychiatry, thyrology and therapy for hyperthyroidism. Its mechanism of action is not fully understood, although it is believed to work similarly to iodine. Moreover, ionized lithium inhibits proteolysis of thyroglobulin, ${ }^{12}$ inhibits T4 to T3 conversion, ${ }^{1,9}$ and reduces the concentration of thyroid hormone transport proteins in the blood serum., ${ }^{1,32}$ The data on the effect of $\mathrm{Li}$ on thyroid iodine in the literature is divergent. An increase in iodine uptake after administration of Li was described by Sedvall et al. ${ }^{32}$ The authors demonstrated that Li administered for 12 consecutive days resulted in a decrease in the level of protein-bound iodine in all 7 patients, alongside an increase in iodine uptake from $26 \%$ to $36.7 \%$ after $24 \mathrm{~h}$. Similar results were obtained in animals by Berens et al. ${ }^{33}$ These authors also found that the increased ability of the thyroid to accumulate iodine during Li administration is independent of the degree of prolonged iodine retention in the thyroid. In our study, administration of $\mathrm{Li}$ according to the proposed regimen caused a significant increase of RAIU in all patients after adjuvant therapy, and iodine uptake increased from approx. $12 \%$ to $24 \%$ and from $25 \%$ to $41 \%$ after $24 \mathrm{~h}$ in comparison to RAIU after $5 \mathrm{~h}$. The results of our research, which are consistent with most of the data available in the literature, have demonstrated the significant role of lithium adjuvant therapy in increasing RAIU.

Different results were presented by Temple et al. ${ }^{34}$ and Turner at al. ${ }^{35}$ Temple et al. studied, among other things, the effect of Li on thyroid RAIU in 11 patients with hyperthyroidism. The initial iodine uptake of $\mathrm{T}_{24 \mathrm{~h}}$ in this group was $33 \pm 88 \%$ and did not change during administration of $900 \pm 1500 \mathrm{mg}$ of Li for 10 days. Turner et al., ${ }^{35}$ on the other hand, administered $400 \mathrm{mg}$ of Li for 1 week before and continued for 1 week after administration 
of a standard therapeutic dose of radioiodine $(5 \mathrm{mCi})$. The $\mathrm{T}_{24 \mathrm{~h}}$ at baseline in this group was approx. $70 \%$, while after administration of $\mathrm{Li}$ it was $67 \%$. Summarizing the obtained results, the authors emphasized the fact that Li only affected the effective half-life of iodine, but did not affect iodine uptake. The basic difference between the groups studied by Sedvall et al., ${ }^{32}$ Turner at al. ${ }^{35}$ and Temple et al. ${ }^{34}$ concerns the initial iodine uptake. In a study by Sedvall et al., ${ }^{32}$ it amounted to $26 \%$, as mentioned above, while in a study by Turner et al., ${ }^{35}$ it was $70 \%$.

In the paper by Bogazzi et al. additional studies were carried out on a group of patients for whom the iodine uptake $\mathrm{T}_{24 \mathrm{~h}}$ was at least $30 \% .{ }^{13}$ The administration of $\mathrm{Li}$ to this group did not significantly increase iodine uptake. Given the literature data and our own observations, it should be assumed that the Li effect depends on the initial value of $\mathrm{T}_{24 \mathrm{~h}}$. If the initial iodine uptake is relatively high, Li may not affect this parameter; however, if it is lower, it should be assumed that Li will likely cause it to increase. As noted above, this is certainly not the only parameter determining the effect of Li. In some patients with reduced $\mathrm{T}_{24 \mathrm{~h}}$, the administration of Li may not have the desired effect. The basic condition for conducting radioisotope treatment of patients with hyperthyroidism is adequately high retention of radioiodine in the thyroid gland. In some patients, it is so low that the use of radioactive iodine is impossible or involves a much higher dose of radioactivity, especially after treatment with amiodarone ${ }^{26}$ or shading agents. ${ }^{36}$

The results of our study confirm the present observations $^{29}$ and indicate that even a few days of administration of Li results in favorable changes in thyroid hormone levels in blood serum, such as decreases in the fT3 and fT4 levels, and has no effect on the TSH level. This result certainly depends on the inhibitory effect of Li on thyroglobulin proteolysis and the secretion of thyroid hormones into the bloodstream. In our study, the serum level of fT3 at baseline in the $\mathrm{Li}(+)$ group was $8.2 \pm 4.1$ $\mathrm{pmol} / \mathrm{L}$ and after $\mathrm{T}_{96 \mathrm{~h}}$ it was fT3 $6.0 \pm 3.1 \mathrm{pmol} / \mathrm{L}$; fT4 at baseline was $29.3 \pm 5.8 \mathrm{pmol} / \mathrm{L}$ and after $\mathrm{T}_{96 \mathrm{~h}}$ it was $24.8 \pm 5.0 \mathrm{pmol} / \mathrm{L}$. The significant effect of short-term administration of $\mathrm{Li}$ on the $\mathrm{T} 3$ level can result from a decrease in the concentration of transport proteins (TBG), which was previously described, but mainly results from inhibition of the conversion of T4 to T3. Jarlov et al..$^{24}$ concluded that administration of $\mathrm{Li}$ at a dose of $32.4 \mathrm{mEq} / \mathrm{day}$ led to a decrease in the level of T4 by $13 \%$ on the $3^{\text {rd }}$ day of the regimen and a $27 \%$ decrease by the $10^{\text {th }}$ day, whereas the decrease in the concentration of T3 in the blood serum (resin test) was $16 \%$ and $38 \%$ on the $3^{\text {rd }}$ and $10^{\text {th }}$ day, respectively.

Data concerning changes in the concentration of thyroid hormones 1 week after administration of a radioisotope can be found in a publication by Bogazzi et al. ${ }^{13}$ and our earlier research. ${ }^{21}$ Bogazzi et al. ${ }^{13}$ evaluated the effect of the administration of Li on the course of treatment with ${ }^{131}$ I in patients with GD. The authors observed a transient increase in $\mathrm{fT} 3$ and $\mathrm{fT} 4$ and an increase in the thyroglobulin level in patients who did not take Li. These changes are likely caused by the direct destructive action of ionizing radiation on follicular cells. This phenomenon was not observed in patients additionally treated with Li. Similar observations were reported by Martin et al. ${ }^{27}$ In our results, which do not deviate significantly from that study, the levels of thyroid hormones after administration of ${ }^{131}$ I were evaluated after 1, 6 and 12 months. It was shown that in this period, the group of patients receiving Li was characterized by significantly lower levels of thyroid hormones. This phenomenon is extremely beneficial in the initial period of radioiodine treatment as it allows for faster euthyreosis than in patients who do not receive Li. Furthermore, it likely allows for avoiding transient increases in thyroid hormone levels as a result of ionizing radiation in the initial period after the administration of ${ }^{131} \mathrm{I}$.

Our findings indicate that the administration of Li for a short period of time does not cause significant changes in serum TSH levels. The TSH was normalized only a few months after the administration of ${ }^{131}$ I. Similar results have been reported by other authors. ${ }^{31,33,37}$

This paper presents a different method of determining the therapeutic activity of radioiodine than used in previous publications on the therapeutic effects of ${ }^{131} \mathrm{I}$ and Li. The recommended dose determination method has now been adopted in clinical practice. The administered ${ }^{131}$ I activity of ${ }^{131} \mathrm{I}$ in patients with toxic adenoma was in each case equal to $555 \mathrm{MBq}(15 \mathrm{mCi})$, while in other cases, an "ablative" dose of $740 \mathrm{MBq}(20 \mathrm{mCi})$ of ${ }^{131} \mathrm{I}$ was used. Despite the use of such a high ${ }^{131}$ I activity for ${ }^{131}$ I, $22 \%$ of patients should have been treated with the second activity of ${ }^{131}$ I. Previous studies used the standard dose ${ }^{38}$ or calculated the radioactivity used per $1 \mathrm{~g}$ of tissue. ${ }^{31}$ Despite these methodological differences, the curative effects shown in the cited works and in our study are similar. The administration of $\mathrm{Li}$ had a positive effect on the efficacy of radioisotope treatment in the early period after the administration of ${ }^{131} \mathrm{I}$.

At one-year follow-up, in the group of patients with GD with $\mathrm{Li}(+)$, hyperthyroidism persisted in approx. $31 \%$ of patients after administration of $\mathrm{Li}$, while remission euthyroidism and hypothyroidism were obtained in $67 \%$ and $57 \%$ of patients, respectively (Table 3$)$. In the $\mathrm{Li}(+)$ group with TMG, recurrent hyperthyroidism was observed in $28.6 \%$ of patients, whereas in patients with TA, no cases of recurrent hyperthyroidism were diagnosed, as judged from biochemical analysis, clinical symptoms and reduced demand for ATD. In the group with toxic nodular goiter, the percentage of successfully treated patients in the $\mathrm{Li}(+)$ group was approx. 25\% (euthyroidism) and 70\% had hypothyroidism; in the toxic adenoma group, it was approx. 70\% (euthyroidism) and in the $\mathrm{Li}(+)$ group of patients, it was approx. 78\% (hypothyroidism). Additionally, clinical signs were less pronounced during follow-up in patients with 
Li(+). Similar percentages were observed for the control group, with hyperthyroidism found in $21.8 \%$ of patients and remission in $78.2 \%$ of patients. Our observations were confirmed by Bogazzi et al., ${ }^{31}$ who demonstrated that adjuvant lithium therapy is more effective, as evidenced by the fact that much better theranostic effects were obtained. Most patients (approx. 84\%, with $\mathrm{Li}(+)$ ) were given a single therapeutic dose of radioiodine.

No significant side effects (e.g., nausea, diarrhea and anorexia) were reported in the studied group of patients after administration of Li. Bogazzi et al. ${ }^{31}$ used a similar treatment protocol (298 patients treated with combined ${ }^{131} \mathrm{I}$ and Li therapy) and reported nausea in $19.4 \%$ of patients and polyuria in $23.9 \%$ of patients, although these changes were not statistically significant.

Burrow et al. ${ }^{39}$ observed side effects in only 2 of 13 patients receiving $900 \mathrm{mg}$ of Li per day. The side effects consisted mainly of enlargement of the thyroid gland. However, goiter regressed after cessation of treatment. In 2015, the European Medicine Agency announced that long-term use of lithium might induce renal tumors. However, a recent study by Ambrosiani et al. ${ }^{40}$ based on 33 years of observation of 1871 lithium patients (clinical records) clearly demonstrated low rates of and mortality due to thyroid or renal cancers in patients receiving permanent adjuvant lithium therapy.

In our study, due to the therapeutic activity of ${ }^{131} \mathrm{I}$, no thyroid goiter was observed in any case. In all cases, goiter was significantly reduced, which was the aim of this treatment.

\section{Limitations}

Our study has some limitations. Firstly, we could not study the level of urinary iodine excretion in this group of patients as an indicator of the overall iodine pool in the body. Therefore, it is assumed that a significant reduction in thyroid iodine uptake capacity as a result of the increased overall pool of iodides in the body might be a possible determinant of Li inefficiency. Secondly, our study did not analyze the titer of the thyroid antibodies in serum; however, it has not been previously observed that short-term administration of Li results in intensification of clinical symptoms (e.g., infiltrative exophthalmos).

\section{Conclusions}

The results of this study of a large cohort of patients with different types of hyperthyroidism (GD, TMN and TA) suggest that a short course of adjuvant lithium and ${ }^{131} \mathrm{I}$ therapy is feasible, highly effective and safe, particularly in patients with low RAIU. Lithium therapy may be a valuable adjunct in this group of patients to reduce thyroid hormone levels.

\section{ORCID iDs}

Maria Teresa Płazińska (D) https://orcid.org/0000-0002-2605-917X Agata Czarnywojtek (D) https://orcid.org/0000-0003-3595-8449 Nadia Sawicka-Gutaj (D) https://orcid.org/0000-0003-1510-4702 Kosma Woliński (D) https://orcid.org/0000-0001-9800-7881 Iwona Krela-Kaźmierczak (D) https://orcid.org/0000-0001-5122-8003 Małgorzata Zgorzalewicz-Stachowiak

(1) https://orcid.org/0000-0001-9260-3674

Izabela Miechowicz (i) https://orcid.org/0000-0003-0751-4867

Paweł Gut (D) https://orcid.org/0000-0002-1661-175X

Ewa Florek (1) https://orcid.org/0000-0002-2689-3009

Karolina Skonieczna-Żydecka (D) https://orcid.org/0000-0002-3430-9079

Marek Ruchała (D) https://orcid.org/0000-0002-6296-7220

Leszek Królicki (D) https://orcid.org/0000-0002-7117-9621

\section{References}

1. Lazarus JH. Lithium and thyroid. Best Pract Res Clin Endocrinol Metab. 2009;23(6):723-733. doi:10.1016/j.beem.2009.06.002

2. Ozpoyraz N, Tamam L, Kulan E. Thyroid abnormalities in lithium-treated patients. Adv Ther. 2002;19(4):176-184. doi:10.1007/BF02848693

3. Deodhar SD, Singh B, Pathak CM, Sharan P, Kulhara P. Thyroid functions in lithium-treated psychiatric patients: A cross-sectional study. Biol Trace Elem Res. 1999;67(2):151-163. doi:10.1007/BF02784070

4. Kallner G, Petterson U. Renal, thyroid and parathyroid function during lithium treatment: Laboratory tests in 207 people treated for 1-30 years. Acta Psychiatr Scand. 1995;91(1):48-51. doi:10.1111/j. 1600-0447.1995.tb09741.x

5. Kirov G. Thyroid disorders in lithium-treated patients. J Affect Disord. 1998;50(1):33-40. doi:10.1016/s0165-0327(98)00028-7

6. Johnston AM, Eagles JM. Lithium-associated clinical hypothyroidism: Prevalence and risk factors. Br J Psychiatry. 1999;175:336-339. doi:10.1192/bjp.175.4.336

7. Fagiolini A, Kupfer DJ, Scott J, et al. Hypothyroidism in patients with bipolar I disorder treated primarily with lithium. Epidemiol Psichiatr Soc. 2006;15(2):123-127. doi:10.1017/s1121189x00004322

8. Shine B, McKnight RF, Leaver L, Geddes JR. Long-term effects of lithium on renal, thyroid, and parathyroid function: A retrospective analysis of laboratory data. Lancet. 2015;386(9992):461-468. doi:10.1016/ S0140-6736(14)61842-0

9. Suwansaksri N, Preechasuk L, Kunavisarut T. Nonthionamide drugs for the treatment of hyperthyroidism: From present to future. Int J Endocrinol. 2018;4:5794054. doi:10.1155/2018/5794054

10. Livingstone $C$, Rampes H. Lithium: A review of its metabolic adverse effects. J Psychopharmacol. 2006;20(3):347-355. doi:10.1177/02698 81105057515

11. Mizukami Y, Michigishi T, Nonomura A, Nakamura S, Noguchi M, Takazakura E. Histological features of the thyroid gland in a patient with lithium induced thyrotoxicosis. J Clin Pathol. 1995;48(6):582-584. doi:10.1136/jcp.48.6.582

12. Robbins J. The Role of TRH and Lithium in the Management of Thyroid Cancer. Rome, Italy: Field Educational Italia; 1981:233-234.

13. Bogazzi F, Bartalena $L$, Brogioni S, et al. Comparison of radioiodine with radioiodine plus lithium in the treatment of Graves' hyperthyroidism. J Clin Endocrinol Metab. 1999;84(2):499-503. doi:10.1210/ jcem.84.2.5446

14. Franklyn JA. The management of hyperthyroidism. N Engl J Med. 1994;330(24):1731-1738. doi:10.1056/NEJM199406163302407

15. Chouhan A, Abhyankar A, Basu S. The feasibility of low-dose oral lithium therapy and its effect on thyroidal radioiodine uptake, retention, and hormonal parameters in various subcategories of hyperthyroid patients: A pilot study. Nucl Med Commun. 2016;37(1):74-78. doi:10.1097/MNM.0000000000000414

16. Bonnema SJ, Hegedüs L. Radioiodine therapy in benign thyroid diseases: Effects, side effects, and factors affecting therapeutic outcome. Endocr Rev. 2012;33(6):920-980. doi:10.1210/er.2012-1030

17. Płazińska MT, Królicki L, Bąk M. Lithium carbonate pre-treatment in 131-I therapy of hyperthyroidism. Nucl Med Rev Cent East Eur. 2011; 14(1):3-8. doi:10.5603/nmr.2011.0002

18. Sawicka-Gutaj N, Ziółkowska P, Sowiński J, et al. Recurrent goiters: Risk factors, patient quality of life, and efficacy of radioiodine therapy. Pol Arch Intern Med. 2019;129(1):22-27. doi:10.20452/pamw.4383 
19. Franklyn JA, Daykin J, Drolc Z, Farmer M, Sheppard MC. Long-term follow-up of treatment of thyrotoxicosis by three different methods. Clin Endocrinol (Oxf). 1991;34(1):71-76. doi:10.1111/j.1365-2265.1991. tb01738.x

20. Allahabadia A, Daykin J, Holder RL, Sheppard MC, Gough SC, Franklyn JA. Age and gender predict the outcome of treatment for Graves' hyperthyroidism. J Clin Endocrinol Metab. 2000;85(3):1038-1042. doi:10.1210/jcem.85.3.6430

21. Lowdell CP, Dobbs HJ, Spathis GS, McCready VR, Cosgrove DO, Harmer CL. Low-dose 131 in treatment of Graves' disease. J Royal Soc Med. 1985; 78(3):197-202. doi:10.1177/014107688507800305

22. Nordyke RA, Gilbert FI Jr. Optimal iodine-131 dose for eliminating hyperthyroidism in Graves' disease. J Nucl Med. 1991;32(3):411-416. PMID:2005449

23. Watson AB, Brownlie BE, Frampton CM, Turner JG, Rogers TG. Outcome following standardized $185 \mathrm{MBq}$ dose 131 therapy for Graves' disease. Clin Endocrinol (Oxf). 1988;28(5):487-496. doi:10.1111/j.13652265.1988.tb03683.x

24. Jarlov AE, Hegedus L, Kristensen LO, Nygaard B, Hansen JM. Is calculation of the dose in radioiodine therapy of hyperthyroidism worthwhile? Clin Endocrinol (Oxf). 1995;43(3):325-329. doi:10.1111/j. 1365-2265.1995.tb02039.x

25. Sridama V, McCormick M, Kaplan EL, Fauchet R, DeGroot L. Long term follow-up study of compensated low-dose 131I therapy for Graves' disease. N Engl J Med. 1984;311(7):426-432. doi:10.1056/NEJM19840 8163110702

26. Czarnywojtek A, Płazińska MT, Zgorzalewicz-Stachowiak M, et al. Dysfunction of the thyroid gland during amiodarone therapy: A study of 297 cases. Risk Ther Clin Manag. 2016;4:505-513. doi:10.2147/TCRM. S96606

27. Martin NM, Patel M, Nijher GM, Misra S, Murphy E, Meeran K. Adjuvant lithium improves the efficacy of radioactive iodine treatment in Graves' and toxic nodular disease. Clin Endocrinol (Oxf). 2012;77(4): 621-627. doi:10.1111/j.1365-2265.2012.04385.x

28. Ruchała M, Sowiński J, Dolata M, Junik R, Gembicki M, Skiba A. Radioiodine treatment of hyperthyroidism in patients with low thyroid uptake. Nucl Med Rev Cent East Eur. 2005;8(1):28-32. PMID:15977144
29. Ruchała M, Szczepanek E. Thyroid ultrasound: A piece of cake? [in Polish]. Endokrynol Pol. 2011;62(Suppl 1):8-24. PMID:22125105

30. Mosteller RD. Simplified calculation of body-surface area. NEngl J Med. 1987;317(17):1098. doi:10.1056/NEJM198710223171717

31. Bogazzi F, Giovannetti C, Fessehatsion $R$, et al. Impact of lithium on efficacy of radioactive iodine therapy for Graves' disease: A cohort study on cure rate, time to cure, and frequency of increased serum thyroxine after antithyroid drug withdrawal. J Clin Endocrinol Metab. 2010;95(1):201-208. doi:10.1210/jc.2009-1655

32. Sedvall G, Jonsson B, Petterson V. Evidence of an altered thyroid function in man during treatment with lithium carbonate. Acta Psychiatr Scand. 1969;207(Suppl):59-66. https://doi.org/10.1111/j.1600-0447.1969.tb0 2045.x

33. Berens SC, Bernstein RS, Robbins J, Wolff J. Antithyroid effects of lithium. J Clin Invest. 1970;49(7):1357-1367.

34. Temple R, Berman M, Robbins J, Wolff J. The use of lithium in the treatment of thyreotoxicosis. J Clinical Invest. 1972;51(10):2746-2756. doi:10. 1172/JCl107094

35. Turner JG, Brownlie BEW, Rogers TGH. Lithium as an adjunct to radioiodine therapy for thyrotoxicosis. Lancet. 1976;1(7960):614-615. doi:10. 1016/s0140-6736(76)90419-0

36. Lee SY, Chang DLF, He X, Pearce EN, Braverman LE, Leung AM. Urinary iodine excretion and serum thyroid function in adults after iodinated contrast administration. Thyroid. 2015;25(5):471-477. doi:10.1089/ thy. 2015.0024

37. Berens SC, Wolff J, Murphy DL. Lithium concentration by the thyroid. J Endocrinol. 1970;87(5):1085-1091. doi:10.1210/endo-87-5-1085

38. Werner SC, Ingbar DH. The Thyroid. Philadelphia, USA: Lippincott Williams \& Wilkins (LWW); 1991:578-585.

39. Burrow GN, Burke WR, Himmelhoch JM, et al. Effect of lithium on thyroid function. J Clin Endocrinol Metab. 1971;32(5):647-652. doi:10.1210/ jcem-32-5-647

40. Ambrosiani L, Pisanu C, Deidda A, Chillotti C, Stochino ME, Bocchetta A. Thyroid and renal tumors in patients treated with long-term lithium: Case series from a lithium clinic, review of the literature and international pharmacovigilance reports. Int J Bipolar Disord. 2018;6(1):17. doi:10.1186/s40345-018-0125-9 